\title{
Taxonomy and Medicinal Uses on Amaranthaceae Family of Rajshahi, Bangladesh
}

\author{
A. H. M. Mahbubur Rahman*, M. Iffat Ara Gulshana \\ Plant Taxonomy Laboratory, Department of Botany, University of Rajshahi, Bangladesh \\ *Corresponding author: ahmmahbubur_rahman@yahoo.com \\ Received February 28, 2014; Revised March 14, 2014; Accepted March 16, 2014
}

\begin{abstract}
Taxonomy and medicinal uses on the family Amaranthaceae growing throughout the Rajshahi, Bangladesh was carried out during September 2011 to December 2012. A total of 14 species under 8 genera belonging to the family Amaranthaceae were collected and identified. Out of the total number of species Achyranthes aspera L., Aerva lanata (L.) Juss. ex Schult., Alternanthera philoxeroides (Mart.) Griseb., Alternanthera sessilis (L.) R. Br. Ex Roem. \& Schult., Amaranthus spinosus L., Amaranthus viridis L., Amaranthus livids L., Amaranthus tricolor L., Amaranthus blitum L., Celosia cristata L., Gomphrena globosa L. were common and Cyathula prostrata (L.) Blume., Digera muricata (L.) Mart., Gomphrena celosioedes Mart. was rare species in the study area. For each species botanical name, local name, habit, habitat, phenology, status of occurrence, chromosome number and medicinal uses have been mentioned.
\end{abstract}

Keywords: Amaranthaceae, Taxonomy, medicinal plants, folkloric uses, rajshahi, bangladesh

Cite This Article: A. H. M. Mahbubur Rahman, and M. Iffat Ara Gulshana, "Taxonomy and Medicinal Uses on Amaranthaceae Family of Rajshahi, Bangladesh." Applied Ecology and Environmental Sciences, vol. 2, no. 2 (2014): 54-59. doi: 10.12691/aees-2-2-3.

\section{Introduction}

A family of about 65 grnera and 900 species, Amaranthaceae are mostly distributed in tropical but also in temperate regions. About 18 genera and over 50 species have been reported from India. Some of the larger genera with the number of their approximately reported species and common names are Alternanthera (200, alligator weed), Gomphrena (100, globe amaranth), Iresine (80, gizzard plant), Amaranthus (60, pigweed), and Celosia (60, Celosia). Ornamental plants of the family known for their multicoloured foliage and beautiful inflorescence are Amaranthus caudatus (Foxtail), A. tricolor, A. salixifolius, Celosia cristata (cocks comb; white, purple or yellowishred panicles), Deeringia amaranthoides, Gomphrena globosa (globe amaranth), Iresine herbtsii (purplish-red foliage) and I. lindenii (red foliage). Edible plants of the family, of which the leaves and young shoots are used as vegetable are Amaranthus blitum (Amaranth or Chaulai), A. caudatus, A. hybridus, A. spinosus (Katili Chaulai), A. tricolor (Bari Chaulai), A. viridis, Celosia argenta and Digera muricata (Lehsua). Inflorescence paste of Achyranthes aspera (Latjeera or Chirchita) is used as an antidote against snake and scorpion bites [16].

The main objectives of this work will be detailed study on the taxonomic and medicinal aspects of the family Amaranthaceae occurring Rajshahi, Bangladesh.

\section{Materials and Methods}

The present study in based on the intensive field of the area during the period of September 2011 to December 2012. A total of 14 species under 8 genera belonging to the family Amaranthaceae were collected and identified. The methods employed during the study were designed with the sole purpose of eliciting the precious wealth of information on the medicinal uses of plants practiced by the local people. Detailed survey has made in gathering information regarding use of medicine has been documented. Usually, the survey in each locality started with the interview of elderly and experienced members, locally known as Hakims. Besides, this the common people of the surveyed localities who themselves have used these plant-based for health treatments were interviewed to prove veracity of the curative features of plants. Medicinal uses and data about the treatment of various alignments based on the information gathered by using questionnaires are given subsequently.

The collected specimens were identified studying related taxonomic books and booklets from the library of Rajshahi University. The major collected materials were identified and described up to species with the help of $[1,2,4,6,8-15]$ were consulted. For the current name and up to date nomenclature $[1,5,7]$ were also consulted. All the collected plant specimens were kept in the Herbarium, Department of Botany, and University of Rajshahi, Bangladesh. 


\section{Results and Discussion}

The present research work is based on the local knowledge of most commonly used medicinal plants of Amaranthaceae family. Each Medicinal plant species is provided with its scientific name, local name, chromosome number (Fedorov, 1969), plant parts (Such as leaf, root, stem, fruit, latex, whole plant, seed, inflorescence and bark) mostly used and uses.

The result obtained in the investigation need to be rigorously subjected to pharmachemical analysis in order to validate their authenticity and future prospects. The paper has only documented the herbal health remedies presently in vogue in the region and does not prescribe or recommend for their use till further determination by the pharmacologist. Data have been gathered on the traditional uses of plant species, especially for asthma, abscess, anthelmintic, astringent, bronchitis, bedsores, cancer, cough, diuretic, diarrhea, dysentery, eczema, earache, headache, inflammations, jaundice, kidney disease, leprosy, paralysis, skin diseases, scabies, toothache, ulcers, ringworm and others.

By examining the plant materials collected from the study area using the identification methods and medicinal information was accumulated and described below.

\subsection{Achyranthes Aspera L.}

Taxonomic description: A perennial herb, 30-90 cm high. Leaves few, 2.5-12.7 cm, elliptic or obovate, round at the apex, generally thick, softly pubescent, tomentose or velvety; flowers small in slender, elongated, terminal spikes, soon deflexed.

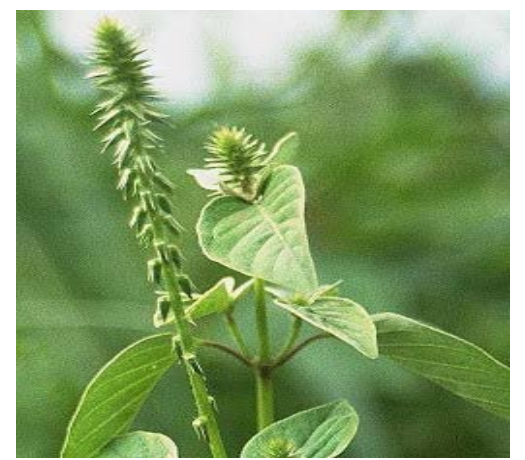

Local name: Apang.

Habit: Herb.

Habitat: Sunny open places, roadsides and waste places.

Phenology: Throughout the year.

Chromosome number: $2 n=14,42$ [3]

Status of occurrence: Common.

Medicinal Uses: Plant is laxative, stomachic, carminative, astringent, depurative, emetic and good diuretic; found efficacious in renal dropsis and general anasarca. Also used in coughs, pneumonia, rheumatism, piles, boils, skin eruptions, kidney stone and colic. The ash of the plant is used in cases of asthma and coughs; mixed with orpiment, the ash is used externally in the treatment of ulcers and warts. Root is used in ophthalmia, dropsy and cutaneous diseases. An infusion of the root is emetic and astringent; reported to be useful for easy delivery and in eczema. The juice of the leaves is taken for dysentery. Seeds are emetic; used in hydrophobia. Paste made of root powder and black pepper is given on acne to cure. The plant extract possesses antifungal properties.

Voucher number: MIAG 20, 23-01-2012, Rajshahi.

\subsection{Aerva lanata (L.) Juss. ex Schult}

An erect or suberect or annual or perennial herb, sometimes with woody base, 10-15 cm. high. Inflorescence sessile, axillary heads or spikes. Fruit an utricle, broadly ovoid, acute, about $1 \mathrm{~mm}$ in diameter. Seeds reniform, black, shining, smooth in the centre, faintly reticulate around the margin.

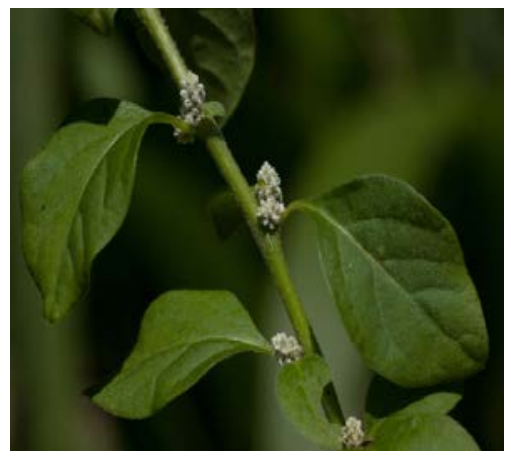

Local name: Chaya.

Habit: Herb.

Habitat: Waste places, roadsides and scrup places.

Phenology: April to July.

Chromosome number: $2 n=16$ [3].

Status of occurrence: Common.

Medicinal Uses: The plant is used as diuretic, demulcent, vermifuge and also used in lithiasis, headache, cough and sudden swellings.

Voucher number: MIAG 21, 30-01-2012, Rajshahi.

\subsection{Alternanthera Sessilis R. Br.}

Taxonomic description: Perennial much branched, prostrate or ascending herb. Leaves opposite, 2.5-7.6 cm long, somewhat fleshy, linear-oblong or lanceolate. Flowers white in small axillary sessile heads.

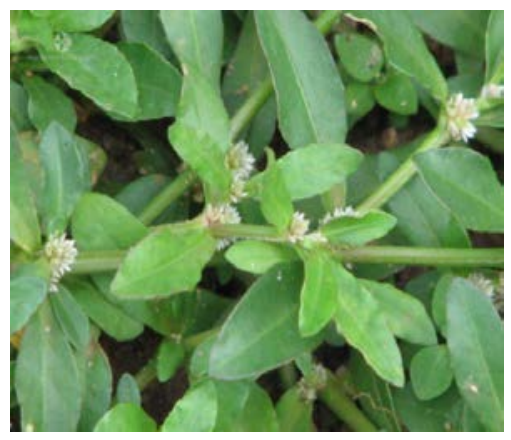

Local name: Chanchi, Sanchi-shak.

Habit: Herb.

Habitat: Wet paddy fields and lowlands.

Phenology: Almost throughout the year.

Chromosome number: $2 n=34,36$ [3]

Status of occurrence: Common.

Medicinal Uses: Plant is galactagogue, cholagogue and febrifuge; Decoction with little salt is drunk to check blood vomiting.

Voucher number: MIAG 03, 06-09-2012, Rajshahi. 


\subsection{Alternanthera Philoxeroides (Mart.) Griseb}

A perennial, polymorphic herb, stem up to $4 \mathrm{~m}$ long when prostrate, up to $30 \mathrm{~cm}$ when erect on dry land, simple or branched, robust, villous to nearly glabrous. Inflorescence a head, head solitary. Ovary pyriform, slightly compressed, stigma large, globose.

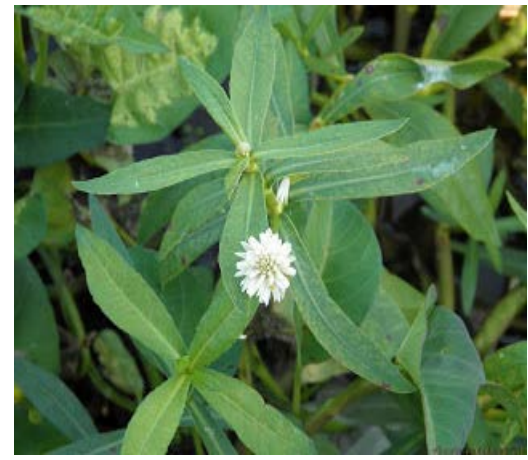

Local name: Malancha shak.

Habit: Herb.

Habitat: Slow moving shallow water, ditches and wet soil.

Phenology: March to June.

Chromosome number: $2 n=68$ [3].

Status of occurrence: Common.

Medicinal Uses: Plant is used for hazy vision, night blindness, malaria, post natal complaints, prolapsus ani, fistulas ani, diarrhoea, dysentery and puerperal fever.

Voucher number: MIAG 19, 05-2011, Rajshahi.

\subsection{Amaranthus Spinosus L.}

Taxonomic description: An annual spinescent herb, 30-60 cm high. Leaves $3.75 \mathrm{~cm}$ long, ovate or oblong, obtuse. Flowers very numerous, sessile, in dense axillary clusters and in terminal dense or interrupted spikes.

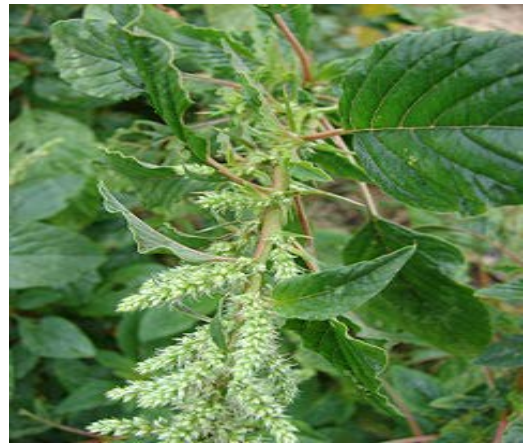

Local name: Kantanotey.

Habit: Herb.

Habitat: Waste land, roadsides, fields and gardens.

Phenology: Throughout the year.

Chromosome number: $2 n=32,34$ [3].

Status of occurrence: Very Common.

Medicinal Uses: The plant is cooling, laxative, diuretic, stomachic, antipyretic and galactagogue; improves appetite; useful in burning sensation, hallucination, leprosy, piles, bronchitis, leucorrhoea, constipation and flatulence. Decoction of the herb is used as a mouth-wash for toothache. The root is heating and expectorant; lessens the menstrual flow; useful in leucorrhoea, leprosy and eczema. It is considered specific in gonorrhea.

Voucher number: MIAG 13, 24-09-2011, Rajshahi.

\subsection{Amaranthus Blitum L.}

A tall, erect, glabrous, succulent herb, upto $42 \mathrm{~cm}$ tall, stem stout, grooved and striate. Inflorescence of axillary clusters and terminal, simple or branched spikes, usually greenish. Fruit an urticle, broadly ovate with a blunt apex, $2 \mathrm{~mm}$ long, indehiscent. Seeds lenticular, black brown, shining, faintly reticulate in the center but smooth at the margin, notched.

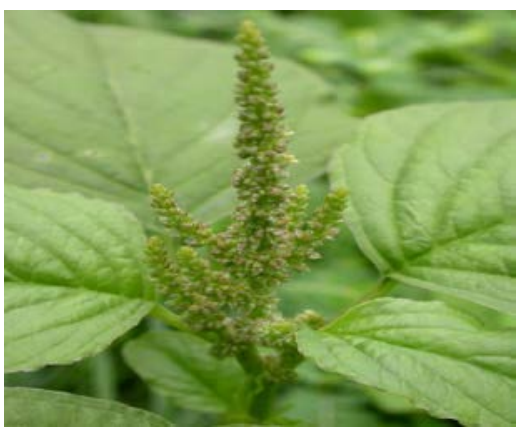

Local name: Datashak, Notiyasag.

Habit: Herb.

Habitat: Dry grassy places and roadsides.

Phenology: Throughout the year.

Chromosome number: $2 n=16,34$ [3].

Status of occurrence: Common.

Medicinal Uses: This plant is used as stomachic, good remedy for the roundworm, emollient and it also used in biliousness, haemorrhagic-diathesis and blisters.

Voucher number: MIAG 33, 30-09-2011, Rajshahi.

\subsection{Amaranthus Lividus Willd}

A herbaceous weed plant 20-35 cm high, with stems prostrate or ascending, only red at the bottom. Ovate leaves typically recorded at the apex. Inflorescences greenish glomerule (a compact, cymose cluster of flowers) in the axils of leaves. Bracts shorter than the perianth (Outer envelope of a flower).The flower colour is Violet / Purple. Found growing on waste ground.

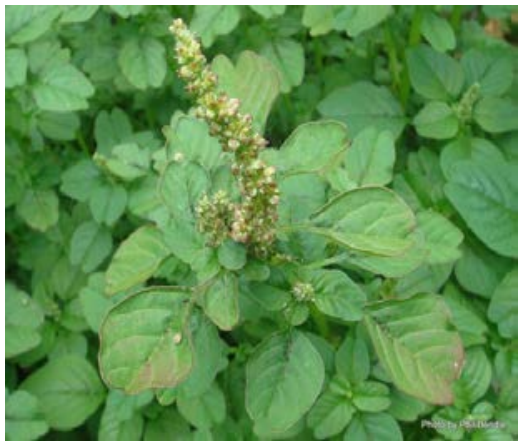

Local name: Goburanotey.

Habit: Herb.

Habitat: Roadsides, waste lands.

Phenology: January to April.

Chromosome number: $2 n=34$ [3]

Status of occurrence: Common. 
Medicinal Uses: The boiled leaves and roots are given to children as a laxative; they are applied as an emollient poultice to abscessess, boils and burns. Root juice along with sugar or molasses is given in dysentery.

Voucher number: MIAG 06, 30-03-2012, Rajshahi.

\subsection{Amaranthus Viridis L.}

An erect, branched annual herb, 30-60 cm high; branches often purplish. Leaves long-petioled, ovate, 2.5-5 $\mathrm{cm}$, variable in breadth. Flowers minute, pale green, in small axillary clusters and in slender tapering terminal and axillary paniculate spike-like racemes.

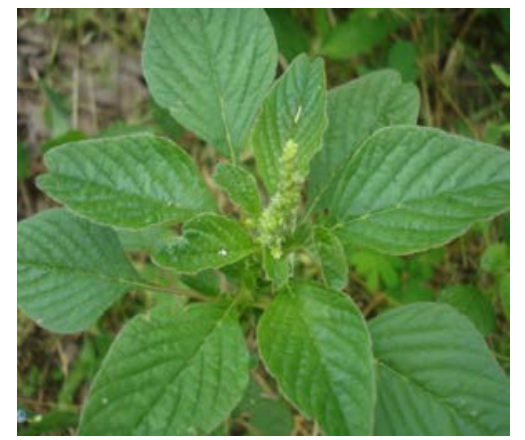

Local name: Shaknotey.

Habit: Herb.

Habitat: Roadsides, waste lands.

Phenology: Throughout the year.

Chromosome number: $2 n=34$ [3].

Status of occurrence: Common.

Medicinal Uses: The plant is cooling, alexiteric, laxative, stomachic, appetizer and antipyretic; used in burning sensation, hallucination, leprosy, bronchitis, piles, leucorrhoea and constipation. The leaves are used as an emollient. The root is heating and expectorant; lessens the menstrual flow; useful in leucorrhoea and leprosy.

Voucher number: MIAG 08, 04-03-2012, Rajshahi.

\subsection{Amaranthus Tricolor $L$.}

An annual, ascending or erect herb, attaining $1.2 \mathrm{~m}$ high or more in cultivation, stem stout, usually much branched, branches angular, glabrous. Inflorescence a head, axillary and terminal. Fruit circumscissile below the middle, ovoid, $1.5 \mathrm{~mm}$ long. Seeds ovoid, $1.5 \mathrm{~mm}$ in diameter, shining, brown, smooth, lenticular.

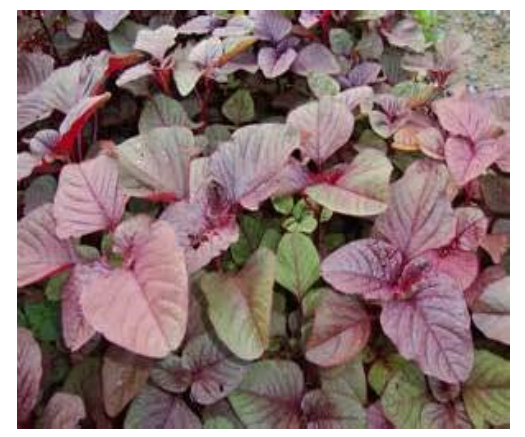

Local name: Lalshak.

Habit: Herb.

Habitat: Dry grassy places and roadsides.

Phenology: Throughout the year.

Chromosome number: $2 n=34$ [3].

Status of occurrence: Very common.
Medicinal Uses: The plant is cooling, alexiteric, laxative, stomachic, appetizer and antipyretic; used in burning sensation, hallucination, leprosy, bronchitis, piles, leucorrhoea and constipation.

Voucher number: MIAG 07, 09-04-2012, Rajshahi.

\subsection{Celosia Criatata L.}

An erect, much branched, annual herb or subshrub, 45$92 \mathrm{~cm}$ tall, stem slender, glabrous, striped, sometimes slightly woody. Inflorescence variously branched, cockcomb like terminal and axillary spikes. Fruit a circumscissile capsule, thin, ovoid to almost globular, 1.6 to $2.5 \mathrm{~mm}$ long. Seeds few, reniform, compressed, black, shining, finely reticulate.

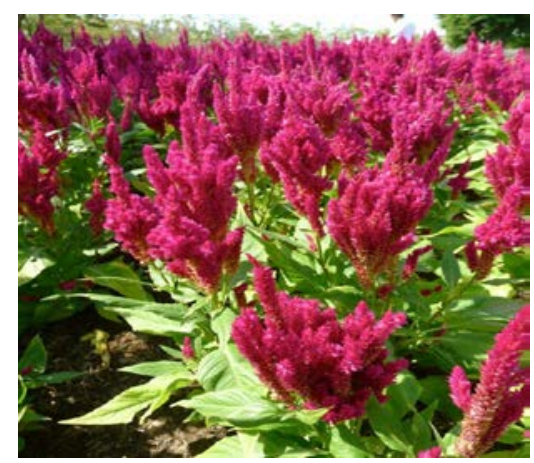

Local name: Moragphul.

Habit: Herb.

Habitat: Gardens.

Phenology: Throughout the year.

Chromosome number: $2 \mathrm{n}=36$ [3]

Status of occurrence: Common.

Medicinal Uses: The plant is used in biliousness, dysentery, diarrhea, painful menstruation, snake-bite and also used as demulcent, alexiteric, astringent, emollient for opthalmia.

Voucher number: MIAG 05, 10-06-2012, Rajshahi.

\subsection{Cyathula Capitata Moq}

Taxonomic description: A slender annual herb, often gregarious, prostrate to ascending or erect, rooting at the base, 20-45 cm long, stem and branches obtusely quadrangular to sub-terete striate. Fruit an ovoid, membranous utricle, enclosed in the perianth surmounted by the remains of the style, glabrous, about $1.5 \mathrm{~mm}$ long, indehiscent. Seeds ovoid-oblong, shining-brown, smooth.

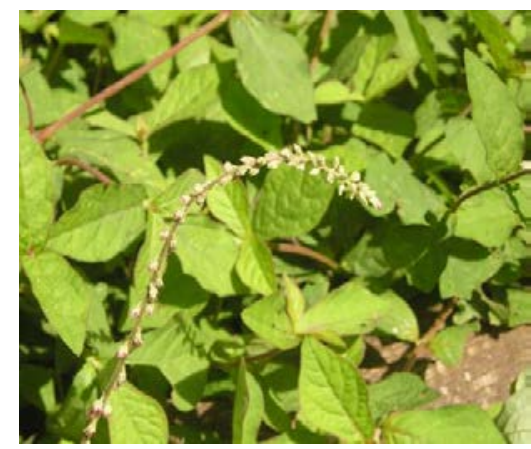

Local name: Boroapang.

Habit: Herb.

Habitat: Roadsides and dry grassy places.

Phenology: September to November. 
Chromosome number: $2 \mathrm{n}=48$ [3].

Status of occurrence: Rare.

Medicinal Uses: Used for some medicinal purposes against cough, dysentery, cholera and intestinal worms.

Voucher number: MIAG 15, 30-07-2012, Rajshahi.

\subsection{Digera Muricata (L.) Mart}

Taxonomic description: A slender, annual field weed, 30-60 cm high. Leaves 2-7.5 cm long, ovate or elliptic, acute or rounded at the apex. Flowers rose-coloured, sessile, in threes on lax, axillary, pedunculate spikes, 2.5$12.5 \mathrm{~cm}$ long. Fruit 2.5-3 mm diam., globose, somewhat compressed.

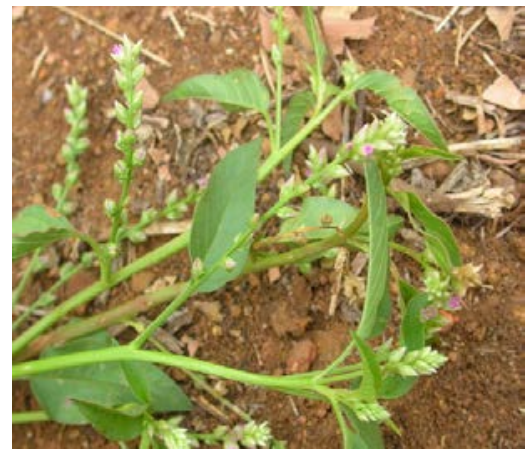

Local name: Latamouri, Digera.

Habit: Herb.

Habitat: Cultivated lands and along roadsides.

Phenology: February to July.

Chromosome number: $2 n=12,18$ [3]

Status of occurrence: Very rare.

Medicinal Uses: Plant is cooling, astringent to the bowels in small doses and laxative in large doses; useful in biliousness. Flowers and seeds are useful in urinary discharges.

Voucher number: MIAG 25, 30-08-2012, Rajshahi.

\subsection{Gomphrena Celosioides Mart}

Taxonomic description: A perennial, prostrate to ascending suberect herb, upto $30 \mathrm{~cm}$ long, much branched from the base and above. Fruit a capsule, shortly compressed, pyriform, 1.6 to $2.5 \mathrm{~cm}$ long. Seeds compressed, ovoid, faddish-brown, shining, faintly lenticular.

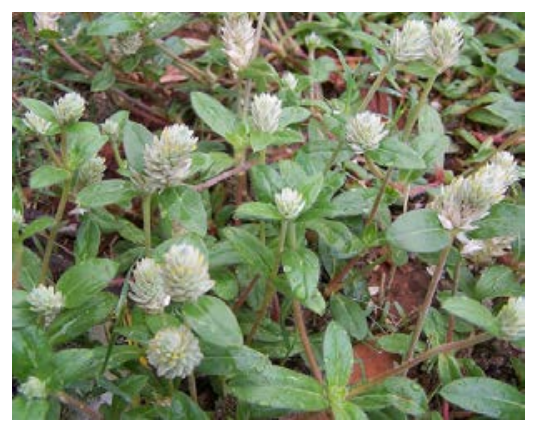

Local name: Bonnobotaphul.

Habit: Herb.

Habitat: Waste lands, roadsides, dry sandy soil.

Phenology: June to October.

Chromosome number: $2 \mathrm{n}=26$ [3].

Status of occurrence: Rare.
Medicinal Uses: This weed also causes, it is claimed, skin problems in cattle, and hay fever, asthma and dermatitis in some people.

Voucher number: MIAG 55, 30-10-2012, Rajshahi.

\subsection{Gomphrena Globosa L.}

Taxonomic description: An erect or ascending annual herb, up to $50 \mathrm{~cm}$ tall, branched from the base and also above, striate or sulcate, with usually thickened nodes. Inflorescence sessile above the uppermost pair of leaves, usually solitary. Fruit a capsule, oblong-ovoid, compressed, 2.0 by $2.4 \mathrm{~mm}$. Seeds compressed-ovoid, brown, shining, almost smooth.

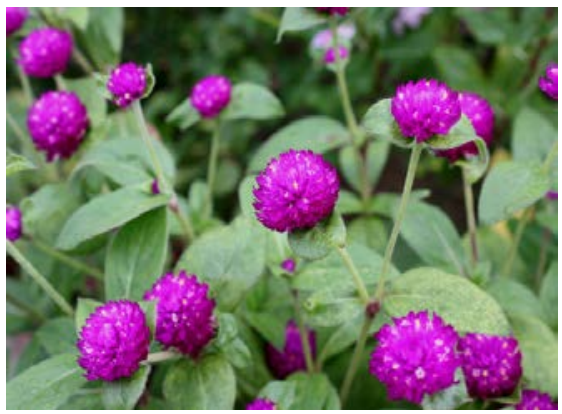

Local name: Botamphul.

Habit: Herb.

Habitat: Gardens and homesteads.

Phenology: June to October.

Chromosome number: $2 n=32$ [3].

Status of occurrence: Common.

Medicinal Uses: Decoction of leaves is used in cough, diabetes and hypertension. Infusion of flower is used in treating oliguria and empacho.

Voucher number: MIAG 45, 30-09-2012, Rajshahi.

\section{Conclusion}

Taxonomy and medicinal uses on the family Amaranthaceae growing throughout the Rajshahi, Bangladesh was carried out during September 2011 to December 2012. A total of 14 species under 8 genera belonging to the family Amaranthaceae were collected and identified. The present study may be a preliminary contribution of this area using standard research methods, focusing on medicinal plants and their local uses for the healthcare. This detailed information will be helpful for the pharmacognosist, botanist, ethno-botanist and pharmacologist for the collection and identification of the plant for their research work and isolation of plant products benefitting human health.

\section{Acknowledgements}

The authors are grateful to the local people of Rajshahi for their co-operation and help during the research work.

\section{References}

[1] Ahmed, Z. U., Z. N. T. Begum, M. A. Hassan, M. Khondker, S. M. H. Kabir, M., Ahmad, A. T. A. Ahmed, A. K. A. Rahman and E. U. Haque. (Eds)., 2007. Encyclopedia of Flora and Fauna of 
Bangladesh. Angiosperms; Dicotyledons. Vol. 6. Asiat. Soc. Bangladesh, Dhaka.

[2] Cronquist, A., 1981. An Integrated System of Classification of Flowering Plants. Columbia University Press. New York.

[3] Fedorov, A.A., 1969. Chromosome Number of Flowering Plants. Academy of Sciences of USSR. Moscow. 926 pp.

[4] Hooker, J.D., 1961. Flora of British India. L. Vols. 1-7. Reeve and Co. Ltd. London.

[5] Huq, A.M., 1986. Plant Names of Bangladesh. Bangladesh National Herbarium, BARC, Dhaka, Bangladesh.

[6] Kirtikar, K.R. and B.D. Basu, 1987. Indian Medicinal Plants. Vols. 1-4. Lalit Mohan Basu, Alhabad, India.

[7] Pasha, M.K. and S.B. Uddin, 2013. Dictionary of Plant Names of Bangladesh (Vascular Plants). Janokalyan Prokashani. Chittagong, Dhaka, Bangladesh.

[8] Prain, D., 1963. Bengal Plants. Vols. 1-2. Botanical Survey of India, Calcutta. India.

[9] Rahman, A. H. M. M., 2013. A Checklist of Common Angiosperm Weeds of Rajshahi District, Bangladesh. Int. J. Agr. Soil Sci. 1 (1): $1-6$.
[10] Rahman, A. H. M. M., 2013. Assessment of Angiosperm Weeds of Rajshahi, Bangladesh with emphasis on medicinal plants. Research in Plant Sciences. 1 (3): 62-67.

[11] Rahman, A. H. M. M., 2013. Angiospermic flora of Rajshahi district, Bangladesh. American Journal of Life Sciences. 1 (3): 105-112.

[12] Rahman, A. H. M. M., 2013. Medico-botanical study of commonly used angiosperm weeds of Rajshahi district,

[13] Rahman, A. H. M. M., S.K. Nitu, Z. Ferdows and A. K. M. R. Islam, 2013. Medico-botany on herbaceous plants of Rajshahi, Bangladesh. American Journal of Life Sciences. 1 (3): 136-144.

[14] Rahman, A.H.M.M., E.Z.M.F. Kabir, A.K.M.R. Islam and A.T.M.N. Zaman, 2013. Medico-botanical investigation by the tribal people of Naogaon district, Bangladesh. Journal of Medicinal Plants Studies. 1 (4): 136-147.

[15] Rahman, A. H. M. M., Z. Ferdous and A. K. M. R. Islam, 2014. A Preliminary Assessment of Angiosperm Flora of Bangladesh Police Academy. Research in Plant Sciences. 2 (1): 9-15.

[16] Sharma, O.P., 2004. Plant Taxonomy. Tata McGraw-Hill Publishing Company Limited, New Delhi, India. 